\title{
AZ ARTIKULÁCIÓS TERÁPIA ÉRTELMEZÉSE AZ IPOO-MODELL ALAPJÁN
}

\author{
Szerzők: \\ Varga Eszter \\ Debreceni Egyetem \\ Szerző e-mail címe: \\ varga.eszter1992@gmail.com
}

\section{Lektorok:}

\author{
Mező Ferenc (Phd) \\ Eszterházy Károly Egyetem \\ Hanák Zsuzsanna (PhD) \\ Eszterházy Károly Egyetem \\ ...és további két anonim lektor
}

\begin{abstract}
Absztrakt
Manapság egyre több olyan gyermekkel találkozunk, aki artikulációs zavarral küzd. A logopédusok munkája elengedhetetlen a megfelelő hangok kialakításában. A tanulmány az artikulációs terápiát mutatja be az IPOOmodell értelmezésében. A tanulmány célja az artikulációs zavar fogalmának, típusainak és terápiájának ismertetése. Ezen kívül az IPOO-modell bemutatására is sor kerül.
\end{abstract}

Kulcsszavak: artikulációs zavar, artikulációs terápia, IPOO-modell

Diszciplina: gyógypedagógia

\begin{abstract}
INTERPRETATION OF ARTICULATION THERAPY ON THE BASIS OF THE IPOO MODEL

Today, more and more children are encountered who have articulation disorders. The work of speech therapists is indispensable. The study presents articulation therapy with the help of the IPOO model. The purpose of this study is to describe the concept, types and therapy for articulation disorders. In addition, the IPOO model will be presented.
\end{abstract}

Keywords: articulation disorder, therapy, IPOO model

Disciplines: special education

Varga Eszter (2019): Az artikulációs terápia értelmezése az IPOO-modell alapján. OxIPO - interdiszciplináris tudományos folyóirat, 2019/2, 71-75. doi: 10.35405/OXIPO.2019.2.71 
Az artikulációs zavar elnevezés helyett a pöszeség kifejezés terjedt el a köznyelvben, azonban a szakma inkább az előbbi megnevezést használja jelenleg. A következőkben említett szerzők még a pöszeség fogalmát alkalmazzák (a fogalomértelmezések a Kovács, 1974 által összeállitott Logopédiai jegyzet I. tankönyvben jelennek meg):

- Nadoleczny szerint a pöszeség bizonyos hangok vagy hangkapcsolatok helyes képzésének vagy kiejtésének képtelensége.

- Lényegében az előzőhöz hasonló szemléletet tükrözi Kanizsai meghatározása is, aki szerint a zavar a hangképzés egy-egy mozzanatára terjed ki.

- Sarbó és Murányi a pöszeséget a beszéd tisztasága zavarának tekinti.

- Hvatcev értelmezésében a pöszeségnél az artikulációs forma és a beszédtartalom egysége bomlik meg.

- Schilling szemlélete szerint a pösze gyermekek esetében a hibát nem egy-egy helyes hang képzésének képtelensége jelenti, hanem az, hogy nem képes azt fonémaként alkalmazni.

Kovács Emőke (1974, 96.) meghatározása szerint „a pöszeség a beszéd tisztaságának olyan zavara, amelyre jellemző az adott nyelvközösség artikulációs normáitól való eltérés...A pöszeséget világszerte a legsűrúbben előforduló beszédhibának tartják." Azonban a legáltalánosabban elfogadott Montágh Imre és társai (2002) pöszeség meghatározása, mely a következő: „az anyanyelv beszédhangjainak következetesen helytelen kiejtését pöszeségnek (artikulációs zavarnak) nevezzük." (Montágh és mtsai., 2002, 66.).

Gósy Mária (2004) szerint a pöszeség több beszédhiba együttes megnevezése. Egyik fajtája a beszéd elhagyása, a másik a beszéd torzítása, a beszédhang nagy mértékú hibás artikulációja, ami gyakorlatilag már egy másik beszédhang.

A pöszeség esetében három csoportot lehet megkülönböztetni a pöszeség oka, kiterjedtsége és tünetei alapján, a következőkben ezek részletesebb kifejtésre kerül sor.

\section{Az artikulációs zavar típusai}

Az artikulációs zavart feloszthatjuk az ok, a kiterjedtség és a tünetek szerint. Emellett még a sérülés helye is nyújthat számunkra felosztási alapot (Thoroczkay Miklósné, 2016).

Az artikulációs zavar oka alapján lehet múködéses (funkcionális) és szervi (organikus) eredetû. Utóbbit még további két részre oszthatjuk: centrális és perifériás.

Az organikus (vagy szervi) pöszeség a beszédszervek fejlődési rendellenességeinek következtében kialakult artikulációs hiba. A beszédszervek sérülései közül a leggyakoribbak a lenőtt nyelvfék, a fognövési rendellenességek, a túlságosan vastag nyelv, illetve az ezeknél sokkal súlyosabb ajak- és szájpadhasadék (helytelenül sokan még napjainkban is nyúlszáj, farkastorok kifejezéssel említik). A beszédjavitást megelőzően vagy azzal párhuzamosan szükséges a helyes beszéd anatómiai feltételeinek megteremtése.

A funkcionális (vagy múködéses) pöszeség egyik legfőbb jellemzője, hogy a beszédszervek épek, azonban a beszédfejlódős során állandósul a helytelen hangképzés. A funkcionális pöszeséget a jól képzett logopédus aránylag könnyen, gyorsan javítja ki (Donászy, 1985).

Mértéke szerint beszélhetünk súlyos fokú általános (diffúz) és enyhe fokú részleges (parciális) artikulációs zavarról.

A megjelenési területe (a sérülés helye) szerint fonetikai szintű (beszédhangzókat érintő) és fonológiai szintû (a nyelvtani szabályok rendszerét is érintô) artikulációs zavar jelenhet meg.

Megjelenési tünete alapján megkülönböztethető:

- felcserélt képzés (paralália): állandó (konstans) vagy változó (inkonstans);

- torzított képzés: a fogak közé csúszik a nyelv (interdentális), fognyomásos (addentális), füttyszerú (stridens), oldalsó (laterális), nyelvháti (dorzális-palatális), orrhangzós (nazális);

- kihagyás, elhagyás (alália). 


\section{Az artikulációs terápia}

Az 53/2016. (XII. 29.) EMMI rendelet egyes oktatási tárgyú miniszteri rendeletek módosításáról alapján a pedagógiai szakszolgálati intézmények múködéséról szóló 15/2013. (II. 26.) EMMI rendelet 25. \(3) bekezdése helyébe a következő rendelkezés lép: „(3) A logopédiai ellátás keretében el kell végezni a harmadik és ötödik életévüket betöltött gyermekek beszéd- és nyelvi fejlettségének szűrését. A hároméveskori logopédiai szűrés a nyelvi fejlettségre (receptív és expreszszív nyelv), az ötéveskori szûrés elsősorban a beszédartikulációra, illetve az írott nyelvi (îrás és olvasás) készültségére irányul."

A logopédus feladatai a szűrést követően a következők:

- az anamnézis felvétele,

- a kóreredet feltárása,

- a tüneti kép pontos leírása,

- a logopédiai vizsgálatok elvégzése,

- esetlegesen felmerülő szakvizsgálatok kérése,

- differenciál-diagnózis felállítása,

- egyéni fejlesztési terv kidolgozása,

- a terápia lefolytatása,

- a terápia lezárásakor a státusz rögzítése,

- az utógondozás és az ellenőrző vizsgálatok megtervezése,

- további kiegészítő terápiák szükségességének jelzése,

- egyes esetekben nyomon követés, utógondozás (Thoroczkay Miklósné, 2016).

A terápia elsődleges célja és feladata az artikulációs hibák kiküszöbölése, a beszéd tisztaságának a helyreállítása. Ezek mellett nagyon fontos a társuló tünetek és nyelvi zavarok rendezése. A logopédusok alapelve, hogy nemcsak a tünetet kezeljük, hanem a komplex fejlesztést helyezzük elótérbe. A terápia részletes ismertetéséhez Thoroczkay Miklósné 2016-os Beszédhangzók fejlesztése módszertani kézikönyvét vesszük alapul. A kezelés menetében több egymástól elhatárolt, de módszertanilag egymásra épült és egymással szoros kapcsolatban lévő szakasz segíti a terápiát. A következőkben a módszertani egységek (elókészítő szakasz, hangfejlesztés, rögzités, automatizálás, motoros differenciálás) bemutatására térünk ki. Fontos megemlíteni, hogy minden szakaszban igyekszünk a fejlesztést életkori szinthez igazítottan, játékosan végezni.

\section{Elökészitö szakasz}

Az előkészítő szakasz első lépéseként az általános képességek fejlesztése történik. Ameddig a gyermek nem rendelkezik tudatos figyelemmel, észlelési szintje nem életkorának megfelelő, nem tud tárolni és visszaidézni, következtetései esetlegesek, tehát ezeknek a területeknek a fejlesztését is be kell terveznünk a terápia menetébe. Ebben a szakaszban történik továbbá még a motoros készségek és az auditív percepció fejlesztése. $\mathrm{Az}$ artikulációs mozgásügyesítő gyakorlatok részeként ajak-, nyelv-, illetve fúvó-, és szívógyakorlatokat végzünk. A nyelvgyakorlatokat mindig a kialakítandó hangnak megfelelóen végezzük (pl. a sz, z, c hangok esetében nyelvhinta végzése). Az auditív figyelem fejlesztése során először a környezet hangjainak, majd az emberi hang (mély-magas, halk-hangos) felismerésére és megkülönböztetésére helyezzük a hangsúlyt. Amennyiben paralália (hangcsere) fordul eló, fontos hogy a kialakítandó és az alkalmazott hang hallási megkülönböztetése szerepet kapjon a terápia során.

\section{Hangfejlesztés}

A hangfejlesztés alkalmával az előkészítés folyamán begyakorolt képességeket használjuk fel. Célunk a hiányzó hang önálló, izolált ejtésú kialakítása. A hangokat mindig hívóképpel (pl. s hang-vonat) együtt gyakoroljuk, s már ebben a szakaszban kialakítjuk a hármas asszociációt: látom-hallom-érzem (kimondom), mely az iskoláskorban a betûtanulás alapfeltétele. A hangfejlesztés történhet indirekt (pl. s hang esetében a vonat hangjának utánzása), illetve direkt (pl. s hang esetében nyelvkanál felemelése a felső fogmederhez, ajkak kerekítése) módon.

\section{Rögrités}

A rögzítés folyamán a fonetikai szabályok figyelembevételével történik a hangzókapcsolatok, szótagsorok megszilárdítása. Feladatunk, hogy az önállóan, izoláltan ejtett, de már stabillá vált fonémát módszeresen 
kapcsoljuk a magánhangzókhoz. A legkönnyebben ejthetô formáktól a fonetikai szabályoknak és a fokozatosságnak a betartásával a legnehezebben ejthető kapcsolatokig haladunk. A rögzítés folyamata a következő: először az új hangzó elöl, majd hátul, végül pedig középen helyezkedik el.

\section{Automatizálás}

Az automatizálás folyamán beépítjük a megszilárdult hangkapcsolatokat a beszédbe. Célunk, hogy a hang helyes ejtése automatikussá váljon. Az automatizálásnál is a rögzítésben leírtakat követjük, tehát a könynyebben kiejthetőtól megyünk a nehezebben artikulálható kapcsolatokig. Az automatizálás menete a szógyakorlatokkal kezdődik, amelyek során először az új hangzó szókezdő, majd szóvégi, szóközi helyzetben van. Végül mássalhangzótorlódásban is automatizáljuk a kialakított hangot. Miután a szavakban történő automatizálás megtörtént, a mondatgyakorlatokkal folytatjuk. Ebben az esetben a fokozatosság elvét alkalmazzuk, tehát egyre nehezebb feladatokat végzünk.

\section{Motoros differenciálás}

Gyakran előfordul, hogy a terápiás folyamatban kialakított, rögzített és automatizált hangok az eddig cserélten ejtett hangzópár jelenlétében nehezen épülnek be a folyamatos beszédbe. A motoros differenciálás akkor kezdődik, amikor a gyermek már a cserélten ejtett hangzópár mindkét hangját helyesen tudja kiejteni. Ebben az esetben is fontos a fokozatosság elvének alkalmazása. Először izolált ejtésben a hívókép-sorok leolvasásával (pl. s-vonat, sz-kígyó) kezdjük meg ezt a szakaszt. Ezután hangzókapcsolatokban gyakoroltatjuk a váltogatott szótagsorokat (pl. si-szu). A motoros differenciálás egymásra épülő gyakorlatait a következőképpen végezzük: szavakban (pl. színes), szószerkezetekben (pl. kis szék), oppozíciós szavakban (pl. sószó), mondatokban, történetekben, bővülő mondatszerkezetekben, spontán megnyilatkozásokban.

\section{Artikulációs terápia és IPOO-modell}

Mező Ferenc és Mező Katalin 2007-ben tette közzé a tanulásfejlesztés empirikus kutatása alapján kidolgozott IPOO (input - process - output - organizáció) tanulási modellt (Mező és Mező, 2007). A modell kidolgozói a tanulást információfeldolgozásként értelmezik, ezért összetevőit is az információkezelés folyamata alapján határozzák meg. Ha a tanulást információkkal való múveletek folyamatának tekintjük, akkor az alábbi fázisokat kell végigjárni, esetenként viszszatérve egy-egy korábbi fázishoz:

1) információgyüjtés (input);

2) információfeldolgozás (process);

3) információalkalmazás, felhasználás (output) és

4) tanulásszervezés (organizáció), amely az előzőek eredményességét meghatározza.

A tanulásszervezés szorzati viszonyban áll a másik három elem (input, process, output) összegével, ami azt is jelenti, hogy a legkiválóbb tanulásszervezés sem tudja helyettesíteni az információkkal való megfeleló múveleteket, ugyanakkor a tanulásszervezés mellőzése a többi tényezô magas szintủ jelenléte mellett sem vezethet eredményes tanuláshoz. A különböző fázisokban nyújtott teljesítmény erősítheti, vagy gyengítheti is egymás hatását. Mindegyik fázis sajátos ismeretek, képességek és módszerek érvényesítését igényli. Ezeknek a tanulási alapoknak az aktuális tanulási helyzettel való kölcsönhatása alapvetően befolyásolhatja a tanulás sikeres vagy sikertelen voltát.

$\mathrm{Az}$ artikulációs terápia minden folyamatában (előkészítő gyakorlatok, hangfejlesztés, rögzítés, automatizálás, motoros differenciálás) megjelennek az IPOOmodell különböző fázisai.

Az IPOO-modell alapján az input fázisnak az artikulációs terápiában azt tekinthetjük, amikor a logopédus megmutatja a gyermeknek, hogyan végezze az adott tevékenységet. A logopédus nemcsak megmutatja, hanem minden esetben meg is beszéli a gyermekkel a gyakorlatok folyamatát. Az előkészítő gyakorlatok esetében az ajak-és a nyelvgyakorlatok során is folyamatosan megbeszéli a gyermekkel, hogyan kell az ajkait vagy a nyelvét formálni (pl. a csacsi hangja íá- először széles, mosolygós az ajkad, utána pedig nagyra nyisd ki a szádat). A hangfejlesztés során a kialakítandó hang megfelelő képzését mutatja be és magyarázza el a logopédus (pl. s hang esetében ajakkerekítés, nyelvkanál beemelése a felső fogme-derhez). A rögzítősorokat (pl. su-sü-so-ső-sa-sá-se-sé-si) a gyermek a logopédus után 
mondja. Az automatizálásnál és a motoros differenciálásnál is az utánmondás módszerét alkalmazzuk.

A process fázis jelen esetben annak feleltethetô meg, amikor a gyermek a bemutatott gyakorlatokat ismétli, gyakorolja. Minden feladatot a tükör előtt kell végezni, így a gyermek vizuálisan is össze tudja kapcsolni az éppen végzett cselekvést. Fontos megjegyezni, hogy a logopédiai foglalkozásokon a szakemberek mindig adnak házi feladatot a gyermekeknek, hiszen sajnos a kevés óraszám miatt elengedhetetlen az otthoni gyakorlás. Ennél a fázisnál szükség van a szülők együttműködésére, és fel kell hívni a figyelmüket a gyakorlás fontosságára. Ez a tanulásszervezéssel (organizáció) függ össze.

$\mathrm{Az}$ output fázisban a gyermek hangképzése történik. Ez lehet helyes vagy helytelen. Minden logopédiai foglalkozáson ellenőrizzük a kialakítandó hang kiejtését, és arra törekszünk, hogy minél hamarabb sikerüljön elsajátítania a gyermeknek a helyes képzést.

\section{Összegzés}

A tanulmányban az artikulációs zavar fogalmával, típusaival, illetve terápiájával ismerkedhettünk meg, emellett az artikulációs terápia és az IPOO-modell kapcsolata is bemutatásra került.

Manapság egyre több gyermeknél jelenik meg artikulációs zavar, amely az iskolai teljesítményt is erősen be- folyásolhatja. Emiatt is fontos, hogy minél hamarabb bekerüljenek a gyermekek a terápiába, és megtanulják a hangok helyes képzését.

\section{Irodalom}

Donászy, M., Gereben Ferencné, Laczik Imréné és Vinczéné Bíró, E. (1985). Gyakorlóanyag a pöszeség javitásához: Budapest: Tankönyvkiadó Vállalat.

Gósy, M. (2004). Fonetika, a beszéd tudománya. Osiris kiadó.

Kovács, E. (1974). Logopédiai jegyzet I.. Budapest: Tankönyvkiadó

Mező, F. és Mező, K. (2007). Tanulási stratégiák fejlesz̧tése az IPOO-modell alapján. Debrecen: Tehetségvadász Stúdió - Kocka Kör Tehetséggondozó Kulturális egyesület.

Montágh, I., Vinczéné Bíró, E. és Montághné Riener, N. (2002). Gyakori beszédbibák a gyermekkeorban. Budapest: Nemzeti Tankönyvkiadó.

Thoroczkay Miklósné (2016). Beszédhangzók fejlesztéseMódszertani kézįiönyv. Logopédia Kiadó 